\title{
AnAtomy of Scale. The Migration Crisis IN EUROPE FROM THE PERSPECTIVE OF REFUGEE LAW AND HUMAN RIGHTS LAW
}

\author{
JULIA KAPELAŃSKA-PREGGOWSKA*
}

\begin{abstract}
INTRODUCTION
Individual states used to have an almost unlimited power to organize the rules and procedures for admitting aliens to their territory. In the last decades this sphere of state autonomy has been limited through international standards of refugee and human rights law. It has become even more limited for the EU Member States with the emergence of the Common European Asylum System (CEAS) ${ }^{1}$. The European Union has been slowly building its migration policy since 1999. Today, we speak about second phase CEAS legislation, which consists of several legislative instruments ${ }^{2}$. The system has undergone an evolution, as new needs and gaps have been identified throughout these years. The European Union has created a specific regime of subsidiary protection to cover persons not eligible for refugee status. This mechanism has become a subject of criticism for undermining the efficiency

DOI: $10.1515 /$ wrlae-2018-0025

* Assistant Professor at the Department of Human Rights, Faculty of Law and Administration; Nicolaus Copernicus University in Toruń; jkapre@umk.pl; ORCID: https://orcid.org/0000-0002-7643-2681.

${ }^{1}$ For a time-line see: European Commission, "20 years of migration policy: the path to a European Agenda on Migration" at http://ec.europa.eu/dgs/home-affairs/elibrary/docs/timeline_en/timeline_en.pdf.(last accessed: 12.04.2015).

${ }^{2}$ Currently, the following instruments constitute CEAS: Directive 2011/95/EU of the European Parliament and of the Council of 13 December 2011 on standards for the qualification of third-country nationals or stateless persons as beneficiaries of international protection, for a uniform status for refugees or for persons eligible for subsidiary protection, and for the content of the protection granted (recast), [2011] OJ L 337/9; Directive 2013/32/EU of the European Parliament and of the Council of 26 June 2013 on common procedures for granting and withdrawing international protection (recast), [2013] OJ L 180/60; Directive 2013/33/EU of the European Parliament and Council of 26 June 2013 laying down standards for the reception of applicants for international protection (recast), [2013] OJ L 180/96; Regulation (EU) No. 604/2013 of the European Parliament and of the Council of 26 June 2013 establishing the criteria and mechanisms for determining the Member State responsible for examining an application for international protection lodged in one of the Member States by a third-country national or a stateless person [2013] OJ L $180 / 31$.
\end{abstract}


and narrowing the scope of the 1951 Refugee Convention ${ }^{3}$. Soon after its adoption the interpretation of the Qualification Directive raised some

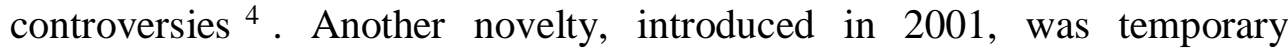
protection that was supposed to be the answer to the problem of a mass influx of refugees. On one hand, the system was theoretically prepared to offer protection to a quite wide range of persons eligible for international protection, but at the same time it was designed to achieve another goal - to prevent "asylum shopping"

This system worked fairly well until mass waves of migrants reached European borders. Persecution, conflict and poverty forced an unprecedented one million people to flee to Europe in 2015, according to the estimates by the UN Refugee Agency, the United Nations High Commissioner for Refugees (UNHCR) and the International Organization for Migration $(\mathrm{IOM})^{6}$. One in every two of those crossing the Mediterranean that year - half a million people - were Syrians escaping war in their country. Afghans accounted for 20 per cent and Iraqis for seven per cent. More than a million migrants and refugees crossed into Europe in $2015^{7}$.

This article explores the "anatomy of scale" and its relevance to the existing regimes of international protection for aliens. The crucial fact that determined the scope of this research was that in cases of a mass influx, the flow of the majority of people is caused by general factors (war, general violence). Thus, the application of existing international and EU standards to the "refugees from war" is analyzed, together with issues such as the type of protection granted to these persons and the scope of the principle of nonrefoulement and non-rejection at the frontier.

As might have been predicted, the system of assessing requests for protection and singling out eligible persons does not work properly in a situation of people coming en masse. This, in fact, technical and practical problem has challenged the whole system and put its underlying principles in question. The so-called migration crisis has proven two things. Firstly, that the temporary protection mechanism is (and will be) a "dead letter" because of lack of solidarity and unanimity. Secondly, that in practice it is very difficult to achieve two goals at the same time; that is, to process large

\footnotetext{
${ }^{3}$ V Chetail, 'Armed Conflict and Forced Migration: Systematic Approach to International Humanitarian Law, Refugee Law, and International Human Rights Law' in A Clapham, P Gaeta (eds), The Oxford Handbook of International Armed Conflict, available at www.oxfordhandbooks.com (last accessed 7.10.2015) 11; P Tiedemann 'Subsidiary Protection and the Function of Article 15(c) of the Qualification Directive' (2012) 31(1) Refugee Survey Quarterly 123-38; R Errera, 'The CJEU and Subsidiary Protection: Reflections on Elgafaji and After' (2011) 23(1) International Journal of Refugee Law 93110; J McAdam, 'The European Union Qualification Directive: The Creation of a Subsidiary Protection Regime' (2005) 17 International Journal of Refugee Law 461-516.

${ }^{4}$ Definition of "indiscriminate violence in situations of international or internal armed conflict” - see CJEU judgment in Case C-285/12 Aboubacar Diakité v Commissaire général aux réfugiés et aux apatrides [2014] ECR-I.

${ }^{5}$ Regulation No. 604/2013 (Dublin III Regulation), previously the Dublin II Regulation.

6 UNHCR, Press Releases, 22 December 2015, available at: http://www.unhcr.org/567918556.html (last accessed 02.03.2016).

7 BBC, Migrant crisis: Migration to Europe explained in graphics, available at: http://www.bbc.com/news/world-europe-34131911 (last accessed 02.03.2016).
} 
numbers of claims for refugee and subsidiary protection and maintain the Dublin Regulation.

When referring to "existing regimes" we need to acknowledge that there are four legal regimes applicable in EU countries: refugee law, international human rights law, international humanitarian law and EU law. The academic literature emphasizes the fragmentation of standards, inconsistencies, problems with cogent application of the existing legal norms and resorts to either a lex specialis approach or calls for a holistic and complementary approach ${ }^{8}$. The article provides references to all four regimes; however, it concentrates on refugee law and human rights law. It first examines the definition of a "mass influx" and the future of temporary protection. It then discusses measures undertaken by the EU and by individual states, aimed at controlling large waves of migrants. In this part, particular attention is given to the issue of non-rejection at the border. The subsequent section outlines human rights standards concerning procedural guarantees and detention conditions. It seeks to demonstrate if the scale of the influx has affected, or may affect, existing standards and principles. In the final part such notions as general violence, differentiated risk and non-refoulement are discussed. This part is mostly based on the analysis of the case law of the European Court of Human Rights, the Committee against Torture and the Court of Justice of the European Union.

\section{DEFINITION OF A "MASS INFLUX" AND THE FUTURE OF TEMPORARY PROTECTION}

The notion "mass influx" itself does not exist in the treaty law. The term can be found in the United Nations General Assembly Declaration on Territorial Asylum of $1967^{9}$ and in the EU Temporary Protection Directive 2001/55/EC of 20 July $2001^{10}$.

"Mass influx" is defined in Article 2(d) of the directive as the arrival of "a large number of displaced persons, who come from a specific country or geographical area whether their arrival in the Community was spontaneous or aided, for example through an evacuation program". For establishing a "mass influx" under the directive it is indispensable to further analyze the notion of "displaced persons". In the light of Article 2(c) 'displaced persons' means "third-country nationals or stateless persons who have had to leave their country or region of origin, or have been evacuated, (...) and are unable to return in safe and durable conditions because of the situation prevailing in that country, who may fall within the scope of Article 1A of the Geneva

\footnotetext{
${ }^{8}$ V Chetail (n 3) 1-2; H Storey, 'Armed conflict in asylum law: the "war-flaw" (2012) 31(2) Refugee Survey Quarterly 1.

${ }^{9}$ Its Article 3(2) provides for an exception to the non-refoulement principle in case of a mass influx, for overriding reasons of national security or in order to safeguard the population. ${ }^{10}$ Council Directive 2001/55/EC of 20 July 2001 on minimum standards for giving temporary protection in the event of a mass influx of displaced persons and on measures promoting a balance of efforts between Member States in receiving such persons and bearing the consequences thereof, [2001] OJ L 212/12.
} 
Convention ${ }^{11}$ or other international or national instruments giving international protection, in particular:

(i) persons who have fled areas of armed conflict or endemic violence;

(ii) persons at serious risk of, or who have been the victims of, systematic or generalized violations of their human rights".

This is a very broad definition which, de facto, also offers protection to individuals that would not fall within the scope of the Qualification Directive. Since both acts are elements of one larger system, their interpretation should be unified and coherent. But even if we apply the interpretation of an "armed conflict" and a requirement of the individualization of risk (valid also in the extreme situation of generalized violence in the country of origin ${ }^{12}$ ) suggested by the European Court of Justice (CJEU) with respect to the provisions of the Qualification Directive, it is clear that Article 2(d) of the Temporary Protection Directive will anyway cover all persons fleeing from war or other similar violence. This point will be discussed later in more detail. Moreover, point (ii) has been formulated in a rather broad manner, since it does not refer to a limited catalogue of basic or non-derogable human rights, but to "human rights" in general. In this way, it goes beyond the Qualification Directive. To sum up, a temporary protection applies not only to persons eligible for refugee status and subsidiary protection under the Qualification Directive arriving en masse.

Now, let us proceed to the ratio legis and the aim of the Temporary Protection Directive. According to its Article 1, it is to "(...) establish minimum standards for giving temporary protection in the event of a mass influx of displaced persons (...) and to promote a balance of effort between Member States in receiving and bearing the consequences of receiving such persons". It indeed sets various State's obligations towards persons enjoying temporary protection, but its focus seems to be on the distribution of burdens connected with a mass influx. It thus recalls a notion of "solidarity" between the States on several occasions, and foresees certain mechanisms to put it into practice.

It requires explanation that temporary protection (unlike subsidiary protection) is not a complementary form of protection to the Geneva Refugee Convention and should be seen as "interim protection" or an "interim measure" $"$.It should be triggered not by the appearance of certain groups of aliens at the Europe's door but by the risk that the asylum system will be unable to process the influx without adverse effects for its efficient operation. It is the individual refugee status determination processing capacity of the host State(s) that is crucial here ${ }^{14}$.

The need for an instrument to handle mass influxes of displaced persons from third countries has been highlighted by the arrival of large

\footnotetext{
11 Under EU law this group of persons would be eligible for refugee status under Qualification Directive.

${ }^{12}$ Case C-285/12 Aboubacar Diakité v Commissaire général aux réfugiés et aux apatrides [2014] ECR-I, Case C-465/07 Elgafaji v Staatssecretaris van Justitie, [2009] ECR -I.

${ }^{13}$ International Commission of Jurists, Migration and International Human Rights Law. A Practitioners' Guide No 6 (2014) 93.

${ }^{14}$ M Albert, 'Governance and Refugee Prima Facie Refugee Status Determination: Clarifying the Boundaries of Refugee Protection, Group Determination, and Mass Influx' (2010) 29 (1) Refugee Survey Quarterly 86.
} 
numbers of displaced persons from Bosnia and Kosovo in the 1990s ${ }^{15}$. The numbers we are witnessing today are even higher, that is why one may reflect upon the reasons why the mechanism has not been used so far. Article 5 of the directive provides that the existence of a mass influx of persons shall be established by a Council Decision adopted by a qualified majority. Such a decision has not been adopted probably because the directive encompasses several solidarity clauses and thus would require cooperation and burdensharing from all Member States. Paradoxically, solidarity became "the final nail in the coffin" for the directive. It may be anticipated that the temporary protection directive will remain a "dead letter" and will never be put into practice.

UNHCR has opted for a different approach when dealing with mass migrations - in his "Guidelines for International Protection No. 11" of 24 June 2015 a prima facie recognition of refugee status ${ }^{16}$ is called for. The document defines that "A prima facie approach means the recognition by a State or UNHCR of refugee status on the basis of readily apparent, objective circumstances ${ }^{17}$ in the country of origin or, in the case of stateless asylumseekers, their country of former habitual residence". Furthermore, it explains that such an approach acknowledges that those fleeing these circumstances are at risk of harm that brings them within the applicable refugee definition. Guidelines were adopted to answer the problem of large-scale arrivals when individual status determination is technically difficult and impracticable ${ }^{18}$. What UNHCR suggests is utilizing a rebuttable presumption that all people or certain groups of people fleeing a certain country or countries are at risk of harm and should be granted refugee status ${ }^{19}$. Therefore, in my opinion, it presents a strong position against "differentiated risk".

\footnotetext{
${ }^{15}$ Opinion of the Economic and Social Committee on the "Proposal for a Council Directive on minimum standards for giving temporary protection in the event of a mass influx of displaced persons and on measures promoting a balance of efforts between Member States in receiving such persons and bearing the consequences thereof" (2001/C 155/06), [2001] OJ C 155/21, see also preamble to the directive, point 6 .

${ }^{16} \mathrm{HCR} / \mathrm{GIP} / 15 / 11$, available at:

http://www.unhcr.org/publications/legal/558a62299/guidelines-international-protection-11prima-facie-recognition-refugee.html (last accessed 27.04.2016).

${ }^{17}$ Guidelines suggest that to identify "readily apparent and objective circumstances" country information by will play an important role because UNHCR is often uniquely placed to obtain first-hand information on the causes and motivations of flight 4, para 17. The problem of obtaining information and evidence, as well as of their relevance will be discussed further at the end of the article.

${ }^{18}$ Guidelines (n 16) 3, para 9. The document explains that this approach is not a new invention and that it has been a common practice by states and UNHCR for over 60 years. It has also been mentioned in previous guidelines - UNHCR, "Protection of Refugees in Mass Influx Situations: Overall Protection Framework", 19 February 2001, EC/GC/01/4, available at: http://www.unhcr.org/3ae68f3c24.html, para 6.

19 Presumption could be lifted in individual cases when "Evidence to the contrary is information related to an individual that suggests that he or she should not be considered as a refugee - either because he or she is not a member of the designated group or, although being a member, should not be determined to be a refugee for other reasons (i.a. exclusion)", (n 16) 4, para 18 .
} 


\section{READMISSION AGREEMENTS AND THE PRINCIPLE OF NON- REJECTION AT THE BORDER (NON-REFUSAL OF ENTRY)}

Whilst States are not obliged to admit all aliens to their territory, in the case of a mass influx they may be inclined to use indiscriminate means (covering all migrants, including asylum seekers) to restrict the entry. This leads us to the question whether the principle of non-refoulement encompasses non-rejection at the frontier or an obligation of admission to the territory?

Article 33 of the Refugee Convention (the non-refoulement principle) is believed by the majority of the scholars, including the $\mathrm{UNHCR}^{20}$, to cover not only instances of return but also of non-rejection at the frontier, notwithstanding the scale of influx and its impact on a State's resources, economy or political situation ${ }^{21}$. However, if a mass influx was to additionally jeopardize the safety or security of the local population, an exception could be applied ${ }^{22}$.

Some commentators present voices in favour of a restrictive and literal interpretation of this provision and refer to the travaux preparatoires to the Convention ${ }^{23}$. They rely on the argument that literal understanding of the terms "expel" and "return" implies that a person has to be present on the State's territory. Vincent Chetail, on the other hand, presents a view that international refugee law does not provide a clear-cut answer in favour of either interpretation ${ }^{24}$.

One convincing argument is based on a functional interpretation and the idea that non-refoulement applies to refugees irrespective of whether their status has been formally declared. Recognition of the refugee status of a person is of declarative and not constitutive nature ${ }^{25}$. The Inter-American Court of Human Rights has correctly stated that to interpret it otherwise would render the principle illusory and without content ${ }^{26}$. The same applies to persons at risk of ill-treatment (torture, inhuman and degrading treatment or punishment).

\footnotetext{
${ }^{20}$ See i.a. Conclusions by the Executive Committee of the UNHCR.

${ }^{21}$ GS Goodwin-Gill, J McAdam, The Refugee in International Law (Oxford 2011) 335; J-F Durieux, A Hurwitz, 'How Many is Too Many? African and European Legal Responses to Mass Influxes and Refugees' (2004) 47 GYIL 47 passim; E Lauterpacht, D Bethlehem, 'The scope and content of the principle of non-refoulement: Opinion' in E Feller, V Türk, F Nicholson (eds), Refugee Protection in International Law: UNHCR's Global Consultations on International Protection (Cambridge 2003) 113-115, 119-121.

${ }^{22}$ GS Goodwin-Gill, J McAdam (n 21) 242, citing: UNHCR, The Principle of NonRefoulement as a Norm of Customary International Law: Response to the Questions posed to the UNHCR by the Federal Constitutional Court of the Federal Republic of Germany in Cases 2 BvR 1938/93, 2 BvR 1953/93, 2 BvR 1954/93, 31.01.1994 para 37.

${ }^{23}$ During the drafting process some delegates clearly put forward that "the possibility of mass migrations across frontiers or of attempted mass migrations was not was not covered by article 33". See: UN Doc A/CONF.2 SR.35 (1951), 21 and A/CONF.2/SR.16 (1951) 6.

${ }^{24}$ V Chetail (n 3) 9.

${ }^{25}$ IACtHR, Case of the Pacheco Tineo Family v. Bolivia, judgment of 25.11.2013, para. 145. Also: UNHCR Note on the Principle of Non Refoulement, available at: http://www.refworld.org/docid/438c6d972.html (last accessed 5.12.2015).

${ }^{26}$ IACtHR, Rights and guarantees of children in the context of migration and/or in need of international protection, Advisory Opinion OC-21/14 of 19.08.2014, Series A No. 21 at para 210 .
} 
Similarly, convincing arguments are presented to support a customary character of the non-refoulement and non-rejection principle. Nevertheless, it has to be noted that in 1951 (when the Convention was adopted) the principle of non-refoulement was not a customary norm and it did not encompass nonrejection at the border. Professor Goodwin-Gil presents arguments (based on state practice and opinio iuris) that both "faces" of the principle have become customary since that time ${ }^{27}$.

However, in cases of a mass influx, it is more difficult to give a clear normative answer. Since there is nothing in the text of the Refugee Convention that could serve as a clear guidance, it seems reasonable to concentrate on the State practice and opinio iuris. Although we may find some examples of closing the borders ${ }^{28}$, the practice of the majority of States has been different. On the other hand, an exception to the principle of nonrefoulement in cases of a mass influx was endorsed in the Declaration on Territorial Asylum adopted by the General Assembly in 1967. Its Article 3(2) provides for an exception to the non-refoulement principle in case of a mass influx for overriding reasons of national security or in order to safeguard the population.

Since the mechanism of temporary protection was not, and most probably will not be used, the EU is trying other measures to deal with the mass influx of migrants. During the European Council summit in March 2016, Turkey confirmed its commitment to implementing the bilateral readmission agreement with Greece to accept the rapid return of all migrants not in need of international protection crossing from Turkey into Greece and to take back all irregular migrants apprehended on Turkish waters ${ }^{29}$.

People who do not apply for asylum in Greece or whose applications for asylum have been declared inadmissible or unfounded will be returned to Turkey ${ }^{30}$. Although such measures are not per se in breach of international refugee law and human rights law, two important issues need to be taken into

${ }^{27}$ GS Goodwin-Gil, J McAdam (n 21) 206-208. See also E Lauterpacht, D Bethlehem (n 21) 140-163.

${ }^{28}$ Turkey closed its borders to Kurdish refugees in 1991. Pakistan closed its borders to Afghan refugees in 2000. Further examples of refusals of entry based on the grounds of national security resulting from mass influx in K Long No Entry! A Review of UNHCR's Response to Border Closures in Situations of Mass Refugee Influx (Geneva 2010)

29 Statement of the EU Heads of State or Government, 07.03.2016, http://www.consilium.europa.eu/en/press/press-releases/2016/03/07-eu-turkey-meetingstatement/ (last access 11.03.2016). From 1 June 2016, this will be succeeded by the EUTurkey Readmission Agreement, following the entry into force of the provisions on readmission of third country nationals of this agreement.

${ }^{30}$ Although there should be individual interviews, individual assessments and rights of appeal. The EU asylum rules allow Member States in certain clearly defined circumstances to reject the application without examining the substance. Among the legal possibilities that can be used for declaring asylum applications inadmissible, in relation to Turkey are: 1) first country of asylum (Article 35 of the Asylum Procedures Directive): where the person has already been recognized as a refugee in that country or otherwise enjoys sufficient protection there; 2) safe third country (Article 38 of the Asylum Procedures Directive): where the person has not already received protection in the third country but the third country can guarantee to the readmitted person effective access to the protection procedure on an individual basis and where found to be in need of protection effective access to treatment in accordance with the standards of the Geneva Refugee Convention. 
account when assessing their implementation. First, it has to be remembered that the non-refoulement principle applies not only to the country of origin, but also to any other place, where the persons would face a real risk (danger to their life or freedom) or where no adequate procedural standards are in place, which would protect the individual from an arbitrary deportation to the country of "direct risk" 31 . Another concern relates to detention conditions in Turkey. Since Turkey is not an EU Member State, it does not have to fulfill the standards foreseen in the Reception Directive and Procedural Directive. However, Turkey is a party to the European Convention on Human Rights (ECHR), and should follow the minimum standards as highlighted in the case-law of the European Court of Human Rights (ECtHR) ${ }^{32}$.

Another issue that requires consideration is the legality of measures undertaken at sea, or more generally, a question of how far individual States (or the EU as a whole) could go in restricting entry of aliens into their territory. We have already witnessed examples of "externalization practices" 33 , such as the summary return of asylum seekers from Bulgaria to Turkey in 2014 and $2015^{34}$. Push-backs and interception at sea have been a common practice adopted by many countries, especially by the United States $^{35}$, and has also been utilized by the $\mathrm{EU}^{36}$.

Refusal of entry on international waters raises particular concerns for two reasons. Firstly, because it is more difficult to control and observe the actual practice of the authorities (who may be more inclined to push back

${ }^{31}$ UNHCR, Advisory Opinion on the Extraterritorial Application of Non-Refoulement Obligations under the 1951 Convention relating to the Status of Refugees and its 1967 Protocol, 26.01.2007, 3; E Lauterpacht, D Bethlehem (n 21) 122-123.

${ }^{32}$ MSS v. Greece, ECHR 21.01.2011, appl. no 30696/09; Sharifi v. Austria, ECHR 05.12.2013, appl. no. 60104/08; Tarakhel v. Switzerland, ECHR 04.11.2014, appl. no 29217/12; A.M.E. v. The Netherlands, ECHR inadmissibility decision of 13.01.2015, appl. no 51428/10; A.S. v. Switzerland, ECHR 30.06.2015, appl. no. 39350/13.

${ }^{33}$ Understood as measures applied by a State, outside its national territory, in order to prevent, interrupt or stop the movement of persons without the required documentation crossing international borders by land, air or sea. J Hathaway and T Gammeltoft-Hansen, refer to it "the politics of non-entrée" - Non-Refouement in a World of Cooperative Deterence' (2014) Paper 106 Law and Economics Working Papers 1-64.

34 See a Report by the Human Rights Watch:www.hrw.org/news/2016/01/20/bulgariapushbacks-abuse-borders (last access: 11.01.2016).

${ }^{35}$ Since the 1980's until now, the United States has had a policy of interception at sea to prevent irregular immigration from Haiti and Cuba. See further on the topic: SL Arenilla, 'Violations to the Principle of Non-Refoulement under the Asylum Policy of the United States' (2015) XV Anuario Mexicano de Derecho Internacional 303-306. On Australia's policy of intercepting and transferring all asylum seekers to immigrant detention centres in Manus Island, Papua New Guinea and Nauru see: F McKay, 'A Return to the 'Pacific Solution' (2013) 44 Forced Migration Review, www.fmreview.org/detention/mckay; in USA: 'UN refugee agency calls for adequate asylum screening for Haitian migrants', January 30, 2013, http://www.unhcr.org/cgi$\mathrm{bin} /$ texis/vtx/refdaily?pass $=52 \mathrm{fc} 6 \mathrm{fbd} 5 \&$ date $=2013-01-31 \& \mathrm{cat}=$ Americas $\quad$ (last access: 11.01.2016).

${ }^{36}$ Report of the Special Rapporteur on the human rights of migrants, François Crépeau 'Regional study: management of the external borders of the European Union and its impact on the human rights of migrants' 24.04.2013, A/HRC/23/46, par. 56; Report of the Special Rapporteur on the human rights of migrants, François Crépeau 'Banking on mobility over a generation: follow-up to the regional study on the management of the external borders of the European Union and its impact on the human rights of migrants' 08.05.2015, A/HRC/29/36, para 39. 
migrants without adequate procedural safeguards of individual assessment). Secondly, it engages extraterritorial application of an international obligation not to reject refugees and other persons who fear for their lives and freedom. $\mathrm{UNHCR}^{37}$ as well as other human rights bodies ${ }^{38}$ and leading scholars advocate extraterritorial application of the non-refoulement principle ${ }^{39}$. They rightly observe that to claim otherwise would turn the norm illusory. On the contrary, the US Supreme Court in Sale v. Haitian Centers Council (1993) held that the principle did not have an extraterritorial application ${ }^{40}$. More recently, in a widely-discussed case Hirsi Jamaa v. Italy, the ECtHR stated that interception of asylum seekers on the high seas violated Article 4 of Protocol no. 4 to the ECHR, because the prohibition of collective expulsion generally applies to any measure "the effect of which is to prevent migrants from reaching the borders at the state or even push them back to another state" 41 . Therefore, the Court firmly concluded that the term "expulsion" covers also all means of refusal to authorize entry into national territory ${ }^{42}$. An agreement with Turkey bypasses this prohibition because it obliges Turkey to apprehend migrants in its territorial waters and is not related (connected) with refusal to authorize entry on the part of Greek authorities. The final outcome is, however, the same - that is - prevention from reaching the borders of the EU member states.

\footnotetext{
${ }^{37}$ UNHCR (n 31).

${ }^{38}$ JE Méndez, 'Interim report of the Special Rapporteur on torture and other cruel, inhuman or degrading treatment or punishment' (07.08.2015), A/70/303, 14-15.

${ }^{39}$ On how the principle of non-refoulement applies at sea and translates into a principle of non-rejection at the maritime frontier - S Trevisanut, 'The Principle of Non-Refoulement And the De-Territorialization of Border Control at Sea' (2014) 27 (3) Leiden Journal of International Law 661-675; G Goodwin-Gill, 'The Right to Seek Asylum: Interception at Sea and the Principle of Non-Refoulement' (2011) 23 (3) International Journal of Refugee Law 443-457.

40509 U.S., 155(1993).

${ }^{41}$ Judgment of 23.02.2012, App No 27765/09, para 160. The applicants, eleven Somali nationals and thirteen Eritrean nationals, were part of a group of about two hundred individuals who left Libya in 2009 aboard three vessels with the aim of reaching the Italian coast. On 6 May 2009, when the vessels were within the Maltese Search and Rescue Region of responsibility, they were intercepted by ships from the Italian Revenue Police and the Coastguard. The occupants of the intercepted vessels were transferred onto Italian military ships and returned to Tripoli. On arrival in the Port of Tripoli, the migrants were handed over to the Libyan authorities. The measures were conducted after Italy and Libya signed a bilateral cooperation agreement of 2007, according to which surveillance, search and rescue operations were to be conducted in the departure and transit areas of vessels used to transport clandestine immigrants, both in Libyan territorial waters and in international waters.

${ }^{42}$ See also: Haitian Centre for Human Rights v. United States of America, IACHR, Case 10.675, Report No. 51/96, Merits, 13 March 1997 (Haitian Interdictions Case). The InternAmerican Commission found that returning asylum-seekers, intercepted on the high seas, to their country of origin, suffered a violation of their right to seek asylum in a foreign country.
} 


\section{DETENTION OF ASYLUM-SEEKERS - FOCUS ON ADEQUATE CONDITIONS AND PROCEDURAL GUARANTEES}

Detention of migrants applying for international protection (refugee status or subsidiary protection) is a common practice. Within the EU, the legal basis for detention is provided by national laws implementing the Reception Directive ${ }^{43}$. Article 8 para 1 of the directive provides for a rule that a person should not be held in detention for the sole reason that he or she is an applicant for international protection. It is a last resort measure; that is, if other less coercive alternative measures cannot be applied effectively. Paragraph 3 provides for a list of exceptions when an applicant may be detained - i.a. to determine or verify his or her identity or nationality, to determine those elements on which the application for international protection is based, which could not be obtained in the absence of detention, particularly when there is a risk of absconding and when protection of national security or public order so requires. In a mass migration situation, reasonable arguments could be put forward to justify the necessity of detention, but the mere fact that large numbers of aliens are crossing the border seems not to fall under a risk to national security or public order ${ }^{44}$. In this context, an important preliminary ruling from CJEU is expected soon. In the ruling the Court will reflect on the interpretation and validity of articles 8(3)a) and 8(3)b) of the Reception Conditions Directive in the light of Article 6 Charter of Fundamental Rights of the $\mathrm{EU}^{45}$.

It is clear that in order not to violate international human rights law, detention must be prescribed by law and be non-arbitrary - that is reasonable and proportional to the objectives to be achieved. Sub-paragraphs (a) to (f) of Article $5 \S 1$ ECHR contain an exhaustive list of permissible grounds on which persons may be deprived of their liberty and no deprivation of liberty will be lawful unless it falls within one of those grounds. One of the exceptions, included in sub-paragraph (f), permits the State to detain aliens "to prevent effecting an unauthorized entry into the country" or "against whom action is being taken with a view to deportation". Detention "with a view to deportation" is not limited to instances when the deportation is in progress. It could also cover instances of pending asylum cases since a possible dismissal of the asylum application could open the way to the execution of the deportation orders ${ }^{46}$. However, one cannot disregard the fact

\footnotetext{
${ }^{43}$ Directive 2013/33/EU of the European Parliament and of the Council of 26 June 2013 laying down standards for the reception of applicants for international protection [2013] OJ L 180/96-116.

${ }^{44}$ Case C-601/15 JN v. Staatssecretaris van Veiligheid en Justitie [2016] ECR (Grand Chamber) judgment of 15.02. 2016. CJEU stated that placing or keeping an applicant in detention under point (e) of the first sub-paragraph of Article 8(3) of Directive 2013/33 is, in view of the requirement of necessity, justified on the ground of a threat to national security or public order only if the applicant's individual conduct represents a genuine, present and sufficiently serious threat, affecting a fundamental interest of society or the internal or external security of the Member State concerned (para 67).

${ }^{45}$ Case C-18/16 K v. Staatssecretaris van Veiligheid en Justitie [2016] ECR-I. The case relates to an Iranian national who claimed asylum in the Netherlands.

${ }^{46}$ Nabil and Others v. Hungary, ECHR judgment of 22.09.2015, appl no. 62116/12, para 38.
} 
that while detention might serve a legitimate aim and be necessary, it cannot be arbitrary ${ }^{47}$. The question is, how to assess this condition?

The right to liberty and security enshrined in Article 5 foresees a set of guarantees to ensure that an arrest or detention is fair and justified. Much emphasis in this provision and in the case-law is given to the duration of arrest/detention and to the promptness of legal procedures ${ }^{48}$. In a recent ECtHR judgment against Hungary that concerned asylum proceedings, the Court found that any deprivation of liberty will be justified only for as long as deportation or extradition proceedings are in progress. If such proceedings are not prosecuted with due diligence, the detention will cease to be permissible ${ }^{49}$. The Court indicated that to avoid being branded as arbitrary, detention under Article $5 \S 1$ (f) must be carried out in good faith; it must be closely connected to the ground of detention relied on by the Government and the length of the detention should not exceed time reasonably required for the purpose pursued ${ }^{50}$. What is meant by "reasonably required"? It is a common fact, that in asylum proceedings the quality of evidence presented by the applicant is a major problem and it is often difficult to determine the applicant's identity or nationality. Therefore, it usually takes time to verify the claim. The Court has already considered periods of three and six months' detention pending a determination of an asylum claim to be unreasonably lengthy ${ }^{51}$, but on other occasions it considered periods of eight, or even almost twelve months to be in accordance with the Convention ${ }^{52}$. It follows from the Court's jurisprudence that even if the length of detention is unreasonable, the "overall reasonableness" of detention depends on the conditions of detention ${ }^{53}$. In other words, if conditions are appropriate, even twelve-month-long detention will not amount to the breach of the Convention.

Thus, the efforts should concentrate on the conditions of detention and adequate procedural guarantees. The reality of some EU countries, however, reveals some deficiencies, i.a. failure to guarantee proper legal representation, lack of access for detainees to consular services and interpretation or translation services, lack of appropriate detection procedures for vulnerable

\footnotetext{
${ }^{47}$ As emphasized by the ECHR in case Mahamed Jama v. Malta ECHR 26.11.2015, appl. no $10290 / 13$, para 139 - "It is a fundamental principle that no detention which is arbitrary can be compatible with Article $5 \S 1$ and the notion of "arbitrariness" in Article $5 \S 1$ extends beyond lack of conformity with national law, so that a deprivation of liberty may be lawful in terms of domestic law but still arbitrary and thus contrary to the Convention".

${ }^{48}$ Suso Musa v. Malta, ECHR 23.07.2013, appl. no. 42337/12, (violation of $5 \S 1$ (f) in respect of the applicant's detention that lasted 6 months and particularly in view of his conditions of detention). In contrast, Mahamed Jama v. Malta (n 47) (where no violation was found even though the applicant has been detained pending her asylum application for eight months).

${ }^{49}$ Nabil and Others v. Hungary ECHR 22.09.2015, appl. no. 62116/12, para 33.

${ }^{50}$ Nabil and Others $v$. Hungary (n 49) para 34.

${ }^{51}$ Kanagaratnam v. Belgium ECHR 13.12.2011, appl. no. 15297/09, paras 94-95 and Suso Musa v. Malta (n 48) para 102.

${ }^{52}$ Mahamed Jama v. Malta (n 47); Moxamed Ismaaciil and Abdirahman Warsame v. Malta ECHR 12.01.2016, appl. nos. 52160/13 and 52165/13.

${ }^{53}$ Moxamed Ismaaciil and Abdirahman Warsame v. Malta (n 52) para 142-143.
} 
individuals and lack of recourse to effective remedies ${ }^{54}$. During the last couple of years a significant number of applications have been filed on that ground to the Strasbourg Court ${ }^{55}$. However, the ECtHR has not very often found a violation of the Convention ${ }^{56}$. In general, the place and conditions of detention should be appropriate, bearing in mind that the measure is applicable not to those who have committed criminal offences but to aliens who, often fearing for their lives, have fled from their own country ${ }^{57}$.

The CJEU has also had the opportunity to set the procedural safeguards in asylum proceedings. The case Mukarubega expressly endorsed the right to be heard, as enshrined in the general principle of good administration, in the Return Directive context, and highlighted that it applies in the context of taking a return decision ${ }^{58}$. In Boudjlida the Court stated that the right to be heard implies an obligation upon national authorities to ensure that the person concerned always has the possibility to express his/her point of view on the legality of his/her stay and on possible reasons that may justify the non-adoption of a return decision ${ }^{59}$.

Other possible dangers that might arise as a consequence of a mass influx are accelerated or fast track procedures of dealing with asylum applications. It is of course desirable that the applications are handled quickly and efficiently in order not to detain migrants for long periods, but a balance has to be found between efficiency and fairness (ensuring procedural standards of justice).

\footnotetext{
${ }^{54}$ Report of François Crépeau (n 36) para 52. See also ECHR in Ahmade v. Greece, judgment of 25.09.2012, appl. no. 50520/09, where a whole set of violations were found (art. 3 taken separately and in conjunction with art. 13, art. $5 \S 1$, art. $5 \S 4$ ). More recently: $R$ v. Russia, judgment of 26.01.2016, appl. No 11916/15 and SA. v. Turkey, judgment of 15.12.2015, appl. no 74535/10.

${ }^{55}$ A.S. v. Switzerland, ECHR 30.06.2015, appl. no 39350/13 (no violation of art. 3 and art. 8); A.M.E. v. The Netherlands ECHR inadmissibility decision of 13.01.2015, appl. no 51428/10 (manifestly ill-founded); Mohammadi v. Austria, ECHR 03.07.2014 (no violation of art. 3); Mohammed Hussein v. the Netherlands and Italy, ECHR inadmissibility decision of 02.04.2013 (manifestly ill-founded); Moxamed Ismaaciil and Abdirahman Warsame v. Malta (n 52) (no violation of art. 3 , no violation of $5 \S 1$, violation of art. $5 \S 4$ ).

${ }^{56}$ M.S.S. v. Belgium ECHR 21.01.2011, appl no 30696/09 (violation of art. 13 in conjunction with art. 3 and violation of art. 3); Trakhel v. Switzerland ECHR 04.11.2014 (violation of art. 3); Sharifi and others v. Italy and Greece ECHR 21.10.2014 (violation of art. 13 in conjunction with art. 3, violation of art. 4 of Protocol 4, violation of art. 3).

${ }^{57}$ Nabil and Others $v$. Hungary (n 46) para 34.

${ }^{58}$ Case C-166/13 Sophie Mukarubega v Préfet de police, Préfet de la Seine-Saint-Denis [2014] ECR -I judgment of 5.11.2014.

59 Case C 249/13 Khaled Boudjlida v Préfet des Pyrénées-Atlantiques [2013] ECR - I judgment of 11.12.2014.
} 


\section{ENFORCED RETURN AND THE BENEFICIARIES OF TEMPORARY PROTECTION. NUANCES OF COLLECTIVE EXPULSION}

Let us now move to a question of what would happen to the beneficiaries of temporary protection when the reasons for the protection have ceased to exist (when they would be able to return to their country or region of origin in safe and durable conditions) or when the maximum period of protection had passed (max. 3 years ${ }^{60}$ ). The Temporary Protection Directive foresees the return of persons whose temporary protection has ended and who are not eligible for admission (refugee status or subsidiary protection). It seems that the drafters have overlooked an important discrepancy between the directive and human rights law. The following scenario might happen, which has most probably been overlooked by the policymakers. The directive provides that persons enjoying temporary protection must be able to lodge an application for asylum, but they are not obliged to do that. What would therefore happen to the beneficiaries of temporary protection who did not apply for international protection? Could they be collectively returned? In order to answer this question we need to turn to human rights standards.

Although there is no expressis verbis prohibition of collective expulsions in the International Covenant on Civil and Political Rights (ICCPR), the Human Rights Committee derived it from article 13 of the Covenant ${ }^{61}$. Regional core human rights treaties, on the other hand, all provide for an express prohibition ${ }^{62}$. It is also foreseen in the EU Charter of Fundamental Rights in Article 19 (1).

The core purpose of Article 4 of Protocol no 4 to the ECHR is to safeguard and ensure that each person has been given the opportunity to put arguments against their expulsion to the competent authorities on individual basis $^{63}$. As emphasized by the Court, expulsions need to be carried out following, and on the basis of, a reasonable and objective examination of the particular case of each individual ${ }^{64}$.

While every State has the right to establish its own immigration policy, problems with managing migration flows cannot justify practices incompatible with the State's obligations under the Convention. However, the fact that a number of aliens received similar decisions does not necessarily mean that there is a collective expulsion, on the condition that an

\footnotetext{
${ }^{60}$ There are specific procedures provided in the directive for prolonging the protection, but if we calculate all of them, the maximum period would be 3 years. However, the Member States shall consider any compelling humanitarian reasons which may make return impossible or unreasonable in specific cases (art. 22). The wording of article 22 suggests that it would apply only to extreme situations when humanitarian reasons are "compelling". Thus, return could be possible even if the situation in the country has not improved significantly.

${ }^{61}$ General Comment No 15: The Position of Aliens under the Covenant, UN Doc HRI/GEN/1/Rev.1 at 18 (1986), par. 10.

${ }^{62}$ Art. 4 of Protocol No 4 to ECHR, Art. 22(9) of ACHR, Art. 12 (5) of ACHPR, Art. 26 (b) of the Arab Charter and in Art. 19(1) of the Charter of Fundamental Rights of the EU.

${ }^{63}$ Hirsi Jamaa and Others v. Italy (n 41) para 184.

${ }^{64}$ Georgia v. Russia ECHR (no. 1), 03.07.2014, appl no 13255/07.
} 
individualized examination has taken place ${ }^{65}$. The same reasoning applies to cases of group repatriation ${ }^{66}$.

In this context, one of the ECtHR judgments deserves particular attention. The case Khlaifia and Others $v$. Italy concerned detention in a reception centre on Lampedusa and subsequently on ships moored in Palermo harbour, as well as the repatriation to Tunisia, of clandestine migrants who had landed on the Italian coast in 2011 during the events linked to the "Arab Spring" 67 . The Court further considered that the applicants had suffered a collective expulsion, as their refoulement decisions did not refer to their personal situation; the Court held in particular that an identification procedure was insufficient to disprove collective expulsion. Furthermore, the Court noted that at the time a large number of Tunisians had been expelled under such simplified procedures. Lastly, the Court considered that the applicants had not benefited from any effective remedy in order to lodge a complaint, because under Article 13, if a remedy was to be deemed effective in the case of a collective expulsion it had to have automatic suspensive effect, which in this case meant that it should have suspended the refoulement to Tunisia and that had not been the case. The Court observed that although the applicants had indeed been presented with individual refoulement decisions, the latter had all been identically worded, with no reference to their personal situations, nor had they been interviewed individually. The Court also noted that although the applicants, unlike the migrants in the case of Hirsi Jamaa and Others, had undergone an identification procedure, the latter was insufficient to preclude the existence of collective expulsion.

This analysis could lead to a conclusion that, eventually, expulsion of beneficiaries of temporary protection could only take place after individual assessment of requests for international protection or after other forms of legalization of stay.

Although there are no explicit exceptions or limitations to this prohibition in the provision of Article 4 of Protocol no 4 to the ECHR itself, it is not absolute ${ }^{68}$ since it can be the subject of derogation under article 15 of the Convention. However, it needs to be emphasized that in case of risk of illtreatment in the country of destination (that is covered by a non-refoulement principle), prohibition of collective expulsion becomes absolute.

Taking the above into account it may be surmised that the EU countries refrained from making use of the Temporary Protection Directive primarily because of its strong emphasis on solidarity and, to some extent, also because an alien admitted to the EU is difficult to return.

\footnotetext{
${ }^{65}$ M.A v. Cyprus, ECHR 23.07.2013, appl no. 41872/10 para 254.

${ }^{66}$ Sulejmanovic and Others and Sejdovic v. Italy, ECHR 08.11.2002 friendly settlement, appl no. 57574/00 57575/00.

${ }^{67}$ Khlaifia and Others v. Italy ECHR 01.09.2015, appl no. 16483/12.

${ }^{68}$ Opposite view presented by V Chetail (n 3) 9-10
} 


\section{ANATOMY OF SCALE. GENERAL VIOLENCE, DIFFERENTIATED RISK AND NON-REFOULEMENT}

The concept of refugee status and territorial protection offered to nonnationals is traditionally based on individual factors/situation (sometimes membership of a group) and contingent (dependent) on the existence of persecution ${ }^{69}$. The Refugee Convention reflected these factors in art. 1A(2) (Definition of a refugee) art. 33 (Prohibition of expulsion or return). Both provisions mention the same set of reasons (factors): race, religion, nationality, membership of a particular social group or political opinion. Article 1A (2) further requires establishing a well-founded fear of being persecuted. On the other hand, art. 33 is applicable to refugees whose life or freedom would be threatened on account of one of the reasons listed above.

In cases of a mass influx, the flow of the majority of people is caused by general factors (war, general violence); therefore a question arises, whether the 1951 Convention covers victims of armed conflicts (the so-called "war refugees"). Even though this problem has been a subject of an academic debate for more than three decades, it is still far from being resolved ${ }^{70}$. The points discussed below will illustrate a struggle between the idea that in exceptional situations general risk factors are sufficient to grant international protection, and the idea of "risk differentiation" that requires some individualization of risk in all instances.

The 1979 UNHCR Handbook stated that "persons compelled to leave their country of origin as a result of international or national armed conflicts are not normally [emphasis: J.K-P] considered refugees under the 1951 Convention or 1967 Protocol"71. The idea behind this interpretation was rooted in a view that the fear that is felt indiscriminately by all (or most citizens) as a consequence of civil war is insufficient to offer protection. In other words, a "differential risk" - that would distinguish the asylum seeker from other civilians caught up in the armed conflict - was required from persons fleeing armed conflict. As some indicate, this interpretation has been followed in national practice for two decades ${ }^{72}$. Even more recently the UNHCR did not go as far as to suggest that all civilians affected by an armed conflict or situation of general violence would fall under the scope of article 1 of the Refugee Convention and be treated as refugees. Proving sufficient

\footnotetext{
${ }^{69}$ The notion of persecution is not defined in the refugee law and in international human rights law. It is an evolving concept and the UN High Commissioner for Refugees (UNHCR) has identified some general categories of situations that will amount to persecution - see: UNHCR Handbook paras. 51-60.

${ }^{70}$ W Kälin, 'Refugees and Civil Wars: Only a Matter of Interpretation?' (1991) 3 International Journal of Refugee Law 435-51; M Kagan, W P Johnson, 'Persecution in the For of War: The House of Lords Decision in Adan' (2002) 23 MJIL 247-64; V Holzer, Protection of People Fleeing Situations of Armed Conflict and Other Situations of Violence and the 1951 Convention, Geneva 2012 (UNHCR Legal and Protection Policy Research Series).

${ }^{71}$ UNHCR Handbook on Procedures and Criteria for Determining Refugee Status under the 1951 Convention and the 1967 Protocol Relating to the Status of Refugees, UN Doc. HCR/IP/Eng/Rev.1, (Geneva 1979) para 164.

${ }^{72}$ H Storey (n 8) 5-6; UNHCR, Safe at Last? Law and Practice in Selected EU Member States with Respect to Asylum-Seekers Fleeing Indiscriminate Violence (Geneva 2011).
} 
threat of harm and a nexus with a Convention ground is still required. According to UNHCR, "persons who flee the indiscriminate effects of violence associated with conflict with no element of persecution (...) might not meet the Convention definition, but may still require international protection on other grounds" 73 .

In order to assess the conditions provided for in the Geneva Convention, it is important to concentrate on the type of conflict and to analyze its background and methods of warfare. The notion of "persecution" in conjunction with its grounds, takes a central role in this respect. We may speculate that most contemporary civil wars or non-international armed conflicts (i.a. conflicts in Rwanda or Syria) would pass the test. But what if the cause of conflict is mostly rooted in a fight for power or natural resources (such as diamonds, petroleum) or if we were faced with an international armed conflict for a territory or control over resources? Even in the first group of conflicts, how would we assess a situation of people that are not targeted because of one of the grounds but are clashed between the belligerent parties and may become victims of indiscriminate warfare? In other words, is (civilian) risk of being killed during a war a "persecution"? At this point it should be remembered that these uncertainties at a universal level have led to regional broadening of protection either through a broadened definition of a refugee through an explicit inclusion of persons fleeing armed conflict (Cartagena Declaration and OAU Convention) or a new type of protection (subsidiary protection in EU Qualification Directive).

It has been observed, however, that in defining "persecution" under the Geneva Convention there is a tendency to adhere to the concept of a serious violation of human rights ${ }^{74}$. Fernando M. Mariño Menédez suggests that in recent times the legal distinction between the protection from persecution and protection for other reasons (related to human rights) has become blurred ${ }^{75}$. It is indisputable that independence from the notion of "persecution" made protection from refoulement offered by human rights more generous than the one offered by refugee law.

However, a different problem emerged in human rights, namely what kind of ill-treatment would trigger the protection from refoulement? In other words, could the risk of being killed or injured because of warfare be interpreted as "inhuman", "cruel" or "degrading" treatment? The article will now focus on recent jurisprudence by the Committee Against Torture (CAT), the Court of Justice of the European Union and the European Court of Human Rights related to the "refugees from war" and its possible consequences for national practice in Europe.

\section{Committee against Torture}

\footnotetext{
${ }^{73}$ UNHCR, Interpreting Article 1 of the 1951 Convention Relating to the Status of Refugees (Geneva 2011) para 22.

74 V Chetail (n 3) 11.

${ }^{75}$ V Chetail, 'Recent Jurisprudence of the United Nations Committee against Torture and the International Protection of Refugees’ (2015) Refugee Survey Quarterly 2.
} 
Article 3 of the Convention against Torture and other Cruel, Inhuman, Degrading Treatment or Punishment ${ }^{76}$ does not explicitly mention illtreatment other than torture. However, it has been observed that the Committee emphasizes continuity between various provisions of the Convention and therefore it cannot be excluded that a proven, personal, real and foreseeable risk of prohibited treatment falling short of torture may be covered by the principle of non-refoulement ${ }^{77}$. Fernando M. Mariño Menédez presents a view that the Committee against Torture's jurisprudence is progressively concentrating on the element of "severe pain" and attaches less significance to the reason (motive) or purpose in causing it or to the requirement of risk to be personal ${ }^{78}$. A review of CAT's jurisprudence proves, however, that existence of "personal risk" is required ${ }^{79}$, even in a situation of serious and common breaches of human rights in a country of origin - "(...) the aim (...) is to establish whether the individual concerned would be personally at a foreseeable and real risk of being subjected to torture in the country to which he or she would be returned. It follows that the existence of a pattern of gross, flagrant or mass violations of human rights in a country does not as such constitute sufficient reason for determining that a particular person would be in danger of being subjected to torture on return to that country; additional grounds must be adduced to show that the individual concerned would be personally at risk" $"$.

The rule of "individualization of risk" has nevertheless been mitigated (albeit not straightforwardly) on two occasions; when the Committee dealt with cases concerning countries affected with internal conflicts and serious instability. The first (considered in 2012) concerned Afghanistan. In the CAT's opinion Afghan authorities were at that time unable to protect citizens from the attacks by the Taliban. Moreover, this conclusion referred to the whole territory of the country ${ }^{81}$.The second case concerned a woman who was to be returned to Congo. In this particular case she managed to prove that she had been a victim of torture by FARDC soldiers, however CAT's considerations seemed to have a more general character. The Committee stated that violence against women (including torture and rape) had been used by all parties to the conflict almost on the whole territory of the country ${ }^{82}$. Thus, it could be anticipated, that violation of art. 3 of the Convention would be found, even if a communication was filed by a woman, who had not yet suffered such violence before fleeing Congo.

\section{Court of Justice of the European Union}

\footnotetext{
76 Adopted and opened for signature, ratification and accession by General Assembly resolution 39/46 of 10 December 1984.

${ }^{77}$ M Menédez (n 75) 8.

78 ibid 9.

${ }^{79}$ N.B-M v. Switzerland (2011) comm. no. 347/2008 (expulsion to the Democratic Republic of Congo); $Z v$. Switzerland, opinion 05.05.2015, comm. no 468/2011 (expulsion to Algieria). ${ }^{80}$ Z. v. Denmark, opinion of 10.08.2015, comm. no 555/2013, para 7.2. (expulsion to CHRL); P.S.B. and T.K. v. Canada, opinion of 13.08.2015, comm. no 505/2012, para. 8.3. (expulsion to India); S.K. and others v. Sweden, opinia z 08.05.2015, comm. no 550/2013, para 7.6, 7.11 (expulsion to the Russian Federation).

${ }^{81}$ K.H. v. Denmark (2012) comm. nr. 464/2011, para 8.8.

${ }^{82}$ E.K.W. v. Congo and Finland, opinion of 04.05.2015, comm. no 490/2012, para 9.7, 9.8.
} 
People fleeing from armed conflicts will, in general, be eligible for a subsidiary protection, as article 15 c) of the Qualification Directive defines "serious harm" as "serious and individual threat to a civilian's life or person by reason of indiscriminate violence in situations of international or internal armed conflict". It does not of course preclude the possibility for individuals to apply for refugee status; this would, however, require evidence of persecution foreseen in articles 9 and 10 of the directive.

The major interpretative problem (crucial for a proper application of the directive by domestic bodies) is obvious at first glance - what does "individual threat" mean?

Moreover, the whole sentence seems logically wrong and contradictory. How is it possible to show individual threat in a situation of indiscriminate violence, which by its nature is non-selective and general. This question was addressed by the CJEU in the 2009 Elgafaji judgment ${ }^{83}$. The Court stated then that "(...) the word 'individual' must be understood as covering harm to civilians irrespective of their identity, where the degree of indiscriminate violence characterising the armed conflict taking place (...) reaches such a high level that substantial grounds are shown for believing that a civilian, returned to the relevant country or, as the case may be, to the relevant region, would, solely on account of his presence on the territory of that country or region, face a real risk of being subject to the serious threat (...)" ${ }^{\prime 4}$. The Court continued with a declaration, that this interpretation should be seen as an exception to the rule requiring individual harm ${ }^{85}$. Finally, the CJEU constructed a "sliding scale test", meaning that "the more the applicant is able to show that he is specifically affected by reason of factors particular to his personal circumstances, the lower the level of indiscriminate violence required for him to be eligible for subsidiary protection" 86 . I agree that this test prevents the application of an "either or" or "all or nothing" approach when the level of armed conflict and general violence passes some kind of threshold below which no one is at risk and above which everyone is ${ }^{87}$. Even though the judgment referred to the previous version of the directive ${ }^{88}$, the wording in article $15 \mathrm{c}$ ) remained unchanged ${ }^{89}$, thus the interpretation given by the CJEU is still relevant.

\section{European Court of Human Rights}

The European Convention on Human Rights does not encompass a explicit prohibition of refoulement. However, expulsion by a Contracting State may give rise to an issue under Article 3 ECHR (and hence engage the responsibility of that State under the Convention) when substantial grounds

\footnotetext{
${ }^{83}$ Case C-465/07 Meki and Noor Elgafaji v. Staatssecretaris van Justitie [2007] ECR - I judgment of 17.02.2009.

${ }^{84}$ Case C-465/07 (n 83) para 35.

85 ibid, para 37.

86 ibid, para 39.

${ }^{87}$ H Storey (n 8) 27.

88 Council Directive 2004/83/EC of 29 April 2004 on minimum standards for the qualification and status of third country nationals or stateless persons as refugees or as persons who otherwise need international protection and the content of the protection granted [2004] OJ L 304/12.

${ }^{89}$ Similarly its recital 26 , currently 35 .
} 
have been shown for believing that the person concerned, if deported, faces a real risk of being subjected to treatment contrary to Article 3 .

There have already been several cases brought before the ECtHR, that concerned the non-refoulement principle in an armed-conflict or general violence context (situation). In each of them the Court has reiterated that a general situation of violence will not normally in itself entail a violation of Article 3 in the event of expulsion ${ }^{90}$. Nevertheless, there may be an extreme situation, where the general violence in the country of destination is of such intensity as to create a real risk that any removal to that country would necessarily violate Article $3^{91}$. It thus seemed clear that if this kind of situation was to be identified the person in need of international protection would not have to present any additional evidence of personal risk. If this was not be the case, the assessment of an alleged violation would be relative depending on all the circumstances (both individual and general) of the case. At the same time, the Court made it clear, that the mere possibility of ill-treatment on account of an unsettled situation in the requesting country does not in itself give rise to a breach of Article $3^{92}$.

So far, the European Court of Human Rights has only once identified an extreme case of general violence which entailed a real risk of ill-treatment simply by virtue of an individual being exposed to such violence on return that is, in the judgement in Sufi and Elmi v. United Kingdom of 28 June 2011. The case concerned a situation in Somalia (and more specifically, in its capital - Mogadishu). The assessment of intensity of general violence due to an armed conflict was based on the British practice 4-element test:

1) are parties to the conflict either employing methods and tactics of warfare which increased the risk of civilian casualties or directly targeting civilians

2 ) is the use of such methods and/or tactics widespread among the parties to the conflict

3 ) is the fighting localized or widespread

4) what is the number of civilians killed, injured and displaced as a result of the fighting.

It should to be noted that not only the means of warfare and level of violence were assessed. The Court also took into account other factors, such as: dire humanitarian conditions in refugee camps, lack of reasonable IFA (internal flight alternative) and the fact that the government failed to demonstrate that special circumstances such as powerful clan or family connections could ensure the individual's protection. While the first two factors could be regarded as general because they affected many civilians regardless of their individual characteristics and situation, the third one is of a different nature. It is unclear to me why it has been considered at all, if the Court initially assessed the situation in Somalia as an extreme and exceptional one and stated that all returns would violate art. 3 of the Convention. Moreover, it is controversial to rely on family/clan protection because it is the state that is obliged to protect individuals, not other entities.

\footnotetext{
${ }^{90}$ AA M v. Sweden, ECHR 03.04.2014, appl no. 68519/10, para 62; Sufi and Elmi, ECHR 28.06.2011, appl no 8319/07 and 11449/07, para 241.

91 ibid.

${ }^{92}$ SDM and Others v. the Netherlands, ECHR 12.01.2016, appl no. 8161/07, para 74.
} 
More recently, the Court has reviewed several applications filed by asylum seekers from Syria. When analyzing these judgments we have to acknowledge that the situation in Syria might have been different at the relevant time (during domestic proceedings and the Court's consideration of the case $^{93}$ ) from the one we are witnessing today.

In the applications against Cyprus, a group of asylum seekers alleged that their deportation to Syria had, or would, put them at risk of ill-treatment and/or torture due to their Kurdish origins, referring in particular to Kurds in Syria as an oppressed minority, and their political activities as members of the Kurdish Yekiti Party ${ }^{94}$. In the Court's opinion, unlike to the situation in Somalia (in Sufi and Elmi), "(...) at the relevant time there was no indication that the general situation in Syria for Kurds was so serious that the return of the applicants thereto would constitute, in itself, a violation of Article 3 of the Convention (...)". The Court considered the reports of "serious human rights violations in Syria", but in its view, these were not acts of "(...) such nature or intensity as to show, on their own, that at the relevant time there would have been a violation of the Convention if the applicants were returned to that country" 95 . It needs to be kept in mind that when assessing the general situation in Syria, the Court of course had to rely on the material referring to the situation in 2010 (the time of deportation of the applicants) and not in 2015 (when the judgment was released). In 2010, the Syrian uprising and the ongoing armed conflict in Syria had not yet begun. Therefore, applicants had to prove a real risk of an individual or group nature.

A much more interesting judgment regarding the non-refoulement principle was released in 15 October 2015 (L.M. and others v. Russia) ${ }^{96}$. In this judgment the Court used the Sufi and Elmi test, but also considered additional criteria of essentially individual or group character. The first criterion related to the exact place of origin and residence of the applicants (Aleppo and Damascus) was where exceptionally heavy fighting took place at the relevant time. The second was strictly individual, as it referred to (considered) the fact that the applicant's relatives were killed by armed militia, and that the applicant himself feared that he would be killed too. The third criterion was the ethnic origin of one of the applicants (a stateless Palestinian), which made him a member of a group that was regarded by the UNHCR as being in need of international protection. Finally, the last element that was taken into account was the applicants gender and age (they were young men, who, in the view of the Human Rights Watch, were in particular danger of detention and ill-treatment). Taking all these factors into consideration, the Court found that deportation of the applicants would lead to a violation of art. $3 \mathrm{ECHR}^{97}$. This judgment indicates, in my opinion, that the Court is more likely to use a "differentiated risk" concept or a kind of

\footnotetext{
${ }^{93}$ Regarding the relevant time of assessment with respect to expulsion cases see i.a. $S S v$. the Netherlands, ECHR 12.01.2016, appl no 39575/06) para 63.

${ }^{94}$ HS and Others v. Cyprus, ECHR 21.07.2015, appl nos 41753/10, 41786/10, 41793/10, $41794 / 10,41796 / 10,41799 / 10,41807 / 10,41811 / 10,41812 / 10,41815 / 10,41820 / 10$, 41824/10, 41919/10 and 41921/10)

${ }^{95}$ HS and Others v. Cyprus (n 94) 275.

${ }^{96}$ Appl nos 40081/14 40088/14 40127/14.

${ }^{97}$ In addition there was a violation of article 2 and 5.
} 
"sliding scale" test in the future. It is very unlikely that the Court will come back and elaborate the Sufi and Elmi test and apply the presumption of violation of article 3 ECHR when the risk emanates from the general situation in the country of origin. Even though in an even more recent judgment F.G. v. Sweden, the Court sustained that such possibility is still not excluded ${ }^{98}$, I doubt that it will be applied to the situation of an armed conflict, as in the case of Syria. Although grave violations of human rights and humanitarian law have been reported ${ }^{99}$ (such as bombing of hospitals ${ }^{100}$ ), it will most probably not be regarded as a "most extreme case". Insisting on the presumption would probably mean an open-war between the Court and the majority of $\mathrm{COE}$ Member States.

\section{METHODOLOGY FOR ASSESSING GENERAL SITUATION IN THE COUNTRY OF ORIGIN}

Two major problems may be identified with respect to the mass migrations and assessment of general situation in the countries of origin: methodology and danger of forum shopping. The 2011 Qualification Directive in its Article 4 (Assessment of facts and circumstances) concentrates on evidence provided by the applicant, while with respect to the situation in the country of origin it only briefly foresees that "all relevant facts as they relate to the country of origin at the time of taking a decision on the application; including laws and regulations of the country of origin and the manner in which they are applied".

Similarly, the existing case-law of international judicial and quasijudicial bodies does not offer sufficiently precise guidance as to the kind of evidence, its validity and authority. Moreover, the assessment of a situation by an international body is of little relevance for future domestic practice, unless it provides general guidelines and rules, because the circumstances under review are not static.

The ECtHR recommends that the assessment must be comprehensive and not only analytic ${ }^{101}$. As for the burden of proof, according to a wellestablished case-law, in principle it is for the person seeking international

\footnotetext{
${ }^{98}$ FG v. Sweden, ECHR 23.3.2016 [GC], appl no 43611/11, para 116, where the Court held that if the existence of a real risk of being subjected to treatment contrary to Article 3 of the Convention is established, the applicant's removal would necessarily breach Article 3, "(...) regardless of whether the risk emanates from a general situation of violence, a personal characteristic of the applicant, or a combination of the two. However, it is clear that not every situation of general violence will give rise to such a risk. On the contrary, the Court has made it clear that a general situation of violence would only be of sufficient intensity to create such a risk "in the most extreme cases" where there was a real risk of ill-treatment simply by virtue of an individual being exposed to such violence on return".

${ }^{99}$ See reports of the Independent International Commission of Inquiry on the Syrian Arab Republic, available online at http://www.ohchr.org/EN/HRBodies/HRC/IICISyria/Pages/IndependentInternationalComm ission.aspx (last access: 29.04.2015).

100 https://www.washingtonpost.com/opinions/in-syria-time-for-planb/2016/04/29/024c9b04-0e2b-11e6-bfa1-4efa856caf2a_story.html (last access: 01.05.2015). ${ }^{101}$ NA v. The United Kingdom, ECHR 17.07.2008, appl no. 25904/07, para 130.
} 
protection to adduce evidence in support of non-refoulement. However, in the recent case of F.G. v. Sweden, the Court has explicitly shifted the burden of proof with respect to general factors: "(...) in relation to asylum claims based on a well-known general risk, when information about such a risk is freely ascertainable from a wide number of sources, the obligations incumbent on the States under Articles 2 and 3 of the Convention in expulsion cases entail that the authorities carry out an assessment of that risk of their own motion" 102 . Although this statement reflects usual domestic practice, it may be seen as an additional acknowledgment of an asylum seeker's vulnerability.

In order to assess relevant factors, such as the general situation of the country, the exposure to risk of a particular group or the inexistence of State protection, the ECtHR and CAT rely on State parties' reports, judicial decisions, international organizations and agencies, such as the UNHCR, international human rights bodies and reliable NGO reports ${ }^{103}$. Assessment of the application by domestic bodies ought to follow a similar methodology. It should be "(...) adequate and sufficiently supported by domestic materials, as well as by materials originating from other reliable and objective sources such as, for instance, other Contracting or non-Contracting States, agencies of the United Nations and reputable non-governmental organizations"104.

A clear illustration of the aforementioned problems is provided by one of the domestic decisions (A.A. v. The Secretary of State for the Home Department 105) that concerned expulsion to Iraq. In the opinion of the Upper Tribunal the degree of indiscriminate violence in certain parts of Iraq was so high that it exposed persons to a real risk of serious harm (within the meaning of Article 15(c) of the Qualification Directive) merely due to their presence there. However, other areas of the country (including Baghdad City) did not meet this threshold, therefore internal relocation was deemed reasonable. The Tribunal explicitly noted that its conclusions were contrary to those of the UNHCR and Amnesty International which considered that States should not deny Iraqi nationals international protection on the basis of internal flight alternative. However, it considered that these reports referred to internal flight alternative risks in a generalized way without specific details on particular governorates of Iraq, which had been available in the other evidence before it. This decision was identified to give country guidance (an authoritative finding on the issue identified in the judgment which is binding on other Tribunals which consider the same matters) on Iraq. If domestic bodies responsible for reviewing applications for subsidiary protection and refugee status will pick and choose information and evidence and base their decisions primarily on national material we may end up with several "national standards" of protection instead of a European one. This, of course, would be detrimental both to persons fleeing generalized violence and the common asylum system.

\footnotetext{
${ }^{102}$ FG v. Sweden (n 98) para 126.

${ }^{103}$ CAT, Arkauz Arana v. France, views of 5.06.2000, comm. no. 63/1997, para 11.4; CAT, Pelit v. Azerbaijan, views of 29.05.2007, comm no 281/2005, para 11; Dbouba v. Turkey, ECHR judgment of 13.07.2010, appl no 15916/09, paras 42-43; MB and Others v. Turkey, ECHR 15.06.2010, appl no 36009/08, paras 32-33.

${ }^{104}$ ME v. Denmark, ECHR 08.07.2014, appl no 58363/10, paras 47-51 with further references; SDM and Others v. the Netherlands, ECHR 12.01.2016, appl no 8161/07, para 74.

${ }^{105}$ Upper Tribunal (Immigration and Asylum Chamber), UKUT 00544 (IAC) 30.09.2015.
} 


\section{CONCLuSions}

The scale of migration Europe has been witnessing for the last two years has definitely put into question some of the mechanisms and traditional concepts. Even though the EU was theoretically prepared to absorb largescale migrations through temporary protection, the scale changed social perception and political thinking. Since the current waves of migrations are surely not the last and the biggest ones, Europe has to review its policy and prepare long-term measures. In this process, account needs to be given to human rights law and refugee law, especially with regard to the qualification of persons in need of protection, the non-refoulement and procedural guarantees.

Due to the fact that mass influx migrations are caused by general factors (usually armed conflict, other internal clashes; in the future probably also natural and humanitarian disasters), a fundamental issue will be to assess the general situation in the country of origin in a coherent and uniform manner. Therefore, domestic bodies should be given more guidance through legislation or jurisprudence. The existing "sliding scale" test and the concept of "sufficient intensity" of general violence and "most extreme cases" should be further elaborated.

To sum up, a more general remark could be made that international protection criteria and concepts (notwithstanding whether enshrined in refugee law or human rights treaties) should not be interpreted nationally. It would be ideal to have a universally agreed interpretation in order to avoid the regionalization of protection ${ }^{106}$.

\section{References}

Albert M, 'Governance and Refugee Prima Facie Refugee Status Determination: Clarifying the Boundaries of Refugee Protection, Group Determination, and Mass Influx' (2010) 29 (1) Refugee Survey Quarterly.

Arenilla SL, 'Violations to the Principle of Non-Refoulement Under the Asylum Policy of the United States' (2015) XV Anuario Mexicano de Derecho Internacional.

Chetail V, 'Armed Conflict and Forced Migration: Systematic Approach to International Humanitarian Law, Refugee Law, and International Human Rights Law' in A Clapham, P Gaeta (eds), The Oxford Handbook of International Armed Conflict, available at www.oxfordhandbooks.com (last accessed 7.10.2015).

Chetail V, 'Recent Jurisprudence of the United Nations Committee against Torture and the International Protection of Refugees' (2015) Refugee Survey Quarterly.

Durieux J-F, Hurwitz A, 'How Many is Too Many? African and European Legal Responses to Mass Influxes and Refugees' (2004) 47 GYIL.

\footnotetext{
${ }^{106}$ With this respect I concur with opinions presented by H Storey (n 8) 2.
} 
Errera R, 'The CJEU and Subsidiary Protection: Reflections on Elgafaji and After' (2011) 23(1) International Journal of Refugee Law.

Goodwin-Gill G, 'The Right to Seek Asylum: Interception at Sea and the Principle of Non-Refoulement' (2011) 23 (3) International Journal of Refugee Law.

Goodwin-Gill GS, McAdam J, The Refugee in International Law (Oxford 2011).

Hathaway $\mathrm{J}$ and $\mathrm{T}$ Gammeltoft-Hansen $\mathrm{T}$, Non-Refouement in a World of Cooperative Deterence' (2014) Paper 106 Law and Economics Working Papers.

Holzer V, Protection of People Fleeing Situations of Armed Conflict and Other Situations of Violence and the 1951 Convention, Geneva 2012 (UNHCR Legal and Protection Policy Research Series).

International Commission of Jurists, Migration and International Human Rights Law. A Practitioners' Guide No 6 (2014).

Kagan M, Johnson WP, 'Persecution in the for of War: The House of Lords Decision in Adan' (2002) 23 MJIL

Kälin W, Refugees and Civil Wars: Only a Matter of Interpretation?' (1991) 3 International Journal of Refugee Law.

Lauterpacht E, Bethlehem D, 'The scope and content of the principle of non-refoulement: Opinion' in E Feller, V Türk, F Nicholson (eds), Refugee Protection in International Law: UNHCR's Global Consultations on International Protection (Cambridge 2003).

Long K, No Entry! A Review of UNHCR's Response to Border Closures in Situations of Mass Refugee Influx (Geneva 2010).

McAdam J, 'The European Union Qualification Directive: The Creation of a Subsidiary Protection Regime’ (2005) 17 International Journal of Refugee Law.

McKay F, 'A Return to the 'Pacific Solution' (2013) 44 Forced Migration Review, www.fmreview.org/detention/mckay; in USA: ' $U N$ refugee agency calls for adequate asylum screening for Haitian migrants', January $\quad 30, \quad 2013, \quad$ http://www.unhcr.org/cgi$\mathrm{bin} / \mathrm{texis} / \mathrm{vtx} / \mathrm{refdaily}$ ?pass $=52 \mathrm{fc} 6 \mathrm{fbd} 5 \&$ date $=2013-01-31 \& \mathrm{cat}=$ Americas (last access: 11.01.2016).

Méndez JE, 'Interim report of the Special Rapporteur on torture and other cruel, inhuman or degrading treatment or punishment' 07.08.2015, $\mathrm{A} / 70 / 303$.

Report of the Special Rapporteur on the human rights of migrants, François Crépeau 'Regional study: management of the external borders of the European Union and its impact on the human rights of migrants' 24.04.2013, $\mathrm{A} / \mathrm{HRC} / 23 / 46$.

Report of the Special Rapporteur on the human rights of migrants, François Crépeau 'Banking on mobility over a generation: follow-up to the regional study on the management of the external borders of the European Union and its impact on the human rights of migrants' 08.05.2015, A/HRC/29/36.

Reports of the Independent International Commission of Inquiry on the Syrian Arab Republic, available online at http://www.ohchr.org/EN/HRBodies/HRC/IICISyria/Pages/IndependentInte rnationalCommission.aspx (last access: 29.04.2015). 
Storey H, "Armed conflict in asylum law: the "war-flaw" (2012) 31(2) Refugee Survey Quarterly.

Tiedemann P, 'Subsidiary Protection and the Function of Article 15(c) of the Qualification Directive' (2012) 31(1) Refugee Survey Quarterly.

Trevisanut S, 'The Principle of Non-Refoulement And the DeTerritorialization of Border Control at Sea' (2014) 27 (3) Leiden Journal of International Law.

UNHCR Handbook on Procedures and Criteria for Determining Refugee Status under the 1951 Convention and the 1967 Protocol Relating to the Status of Refugees, UN Doc. HCR/IP/Eng/Rev.1, (Geneva 1979).

UNHCR, Interpreting Article 1 of the 1951 Convention Relating to the Status of Refugees (Geneva 2011).

UNHCR, Safe at Last? Law and Practice in Selected EU Member States with Respect to Asylum-Seekers Fleeing Indiscriminate Violence (Geneva 2011). 